\title{
Comparative Evaluation of Qualitative and Quantitative Phytochemical Analysis of South Indian Bioactive Medicinal Plant Tribulus terrestris
}

\author{
M.S. Uma Maheswari ${ }^{{ }^{*}}$, R.Rajendran ${ }^{2}$ \\ ${ }^{1}$ Department of Microbiology, PSG College of Arts and Science, Coimbatore, India \\ ${ }^{2}$ Department of Microbiology, PSG College of Arts and Science, Coimbatore, India \\ *Corresponding author - maheswariuma938@gmail.com
}

Available online at: www.isroset.org

Received: 10/Dec/2018, Accepted: 21/Dec/2018, Online: 31/Dec/2018

\begin{abstract}
In India researchers are focused on plant medicine to avoid the use of synthetic antibiotics. About $80 \%$ of rural population depends on herbal medicine for their primary health care. Due to the inadequacy of information about their phytochemical and therapeutic properties, some of these sources are still remained unrevealed. In this present study Tribulus terrestris (TT) was collected from local area in and around Gobichettipalayam, Erode and Tiruppur District, India. The qualitative phytochemical analysis of Tribulus terrestris (TT) was performed in seven solvents of Chloroform, Petroleum ether, Acetone, Methanol, Ethanol, Ethyl acetate and Aqueous extracts. The phytochemical analysis of crude extracts of Tribulus terrestris showed the presence of carbohydrates, amino acids, proteins, glycosides, tannins, terpenoids, phenols, alkaloids and saponins. Each crude extract of the plant Tribulus terrestris was comparatively analyzed for presence of phytoconstituents and ethyl acetate has good extractability. The qualitative estimation of Tannins, Alkaloids, and Flavonoids in the Ethyl acetate extract of Tribulus terrestris was determined by the standard methods. The total Tannin, Alkaloid and Flavonoid content of the Ethyl acetate extracts were $2.76 \mu \mathrm{g} / \mathrm{ml}, 0.56 \mathrm{mg} / \mathrm{ml}$ and $0.45 \mathrm{mg} / \mathrm{ml}$. The thin layer chromatography was performed to find most active constituent in all fractions.
\end{abstract}

Keywords: Tribulus terrestris, Phytochemical screening, Leaf Extract, Secondary Metabolites.

\section{INTRODUCTION}

Gokshura (Tribulus terrestris Linn) is one among the ten drugs included under Dasamoola in the Ayurvedic classics. In clinical practice both roots and fruits of this plant are used. Gokshura (Tribulus terrestris Linn) is a procumbent herb and a common plant of wasteland, chiefly in hot, dry and sandy regions, throughout India [1]. The plants are the one of the most important sources of production of medicines. The basis of many traditional medicine systems throughout the world for thousands of years using plants and continue to provide mankind with new remedial action. The bioactive medicinal plants have been the mainstay of traditional herbal medicine amongst rural citizens international while earliest time [2]. Due to wholesale use of artificial antimicrobials, the development of resistant and multi resistant pathogens have been observed [3]

Recurrently, then each and every human beings used plants for a variety of purposes. Most of the medicines are prepared from natural ingredients, specifically from plant sources. The India is the richest country in its plant biodiversity. It is commonly estimated that over 6000 plants in India are used in traditional purpose, folk and herbal medicines [4]. With reference to 3.4 billion people in the developing world depend on plant-based traditional medicine. This represents about 88 percent of the world population, who rely mainly on traditional medicine for their major health care [2]

Natural therapeutics which are derived from plants are more important because of lesser side effects, effective, cost effective and ecofriendly as compared to chemically synthesized medicines. The concentration of phytochemicals is different in different plants and also in different in different parts of the same plant [5]. The awareness of the chemical constituent of plants is attractive because such information will be of importance for the synthesis of complex chemical substances [6].

Phytochemicals are regarded as secondary metabolites because the plants that manufacture them may have little need for them [7]. The therapeutic efficacy of plants depends on their production of secondary compounds such as alkaloids, flavonoids, saponins, terpenoids, steroids, phlobatannins, glycosides, tannins, etc. [5]. Plant Tribulus terrestris is a common shrub found in India. It is an annual plant found in warm and dry tropics of Asia, Africa, Europe, America and Australia[8]. The present study aimed to investigate the biologically active phytochemical properties of Tribulus terrestris. The antibacterial activity of Tribulus terrestris were performed against Escherichia coli and Staphylococcus aureus reported already [9]. 


\section{MATERIALS AND METHODS}

\section{Collection of Plant Material}

Fresh leaves of Tribulus terrestris (Figure 1) free from diseases were collected from in and around Gobichettipalayam, Tirupur and Erode districts. The leaves were washed thoroughly 2-3 times with running tap water and once with sterile distilled water, leaf materials were then air dried and crushed the leaves. The powder of Tribulus terrestris was stored in sterile glass bottle under the shade and used for extraction.

\section{Preparation of plant extract}

\section{Aqueous extraction}

20 grams of air dried fine powder of leaves of $T T$ was infused in double distilled water $(100 \mathrm{ml})$ until complete exhaustion. The extracts were filtered using Whatman filter paper No.1 and the filtrate was kept in a water bath at $80^{\circ} \mathrm{C}$ for 2 hours. The dried crude extracts were kept at $4^{\circ} \mathrm{C}$ for further use.

Solvent extraction (Methanol, Ethanol, Petroleum ether, Chloroform, Ethyl acetate and Acetone, Aqueous)

20 grams of each of the dried powdered materials (leaves) were soaked separately in $100 \mathrm{ml}$ of each of the solvents viz. Ethanol, Methanol, Chloroform, Acetone, Aqueous, Ethyl acetate and Petroleum ether for 24 hours at $31^{\circ} \mathrm{C}$ until complete exhaustion of the material. At the end of 24 hours, each extract was passed through Whatman No 1 filter paper and the filtrates were kept in a water bath at $80^{\circ} \mathrm{C}$ for 2 hours. The paste like extracts were stored in labelled screw capped bottles and kept in a refrigerator $\left(4^{\circ} \mathrm{C}\right)$. Each of the extract was individually diluted using minimal amounts of the extracting solvent prior to use.

Preliminary Qualitative phytochemical analysis of crude extracts

The crude extracts of Tribulus terrestris were subjected to preliminary phytochemical screening for the detection of Terpenoids, Flavonoids ,Phenols , Saponins Tannins, Alkaloids, Proteins, Amino acids, Resins, Oils, Carbohydrates, Steroids and Glycosides. The phytochemical study (colour reactions) was performed with different solvent extracts of Tribulus terrestris using the following procedure. Terpenoids (Salkowski test)

In a test tube $5 \mathrm{ml}$ of solvent extracts was taken and mixed with $2 \mathrm{ml}$ of chloroform and $3 \mathrm{ml}$ of conc. $\mathrm{H}_{2} \mathrm{SO}_{4}$ was carefully added to form a layer. At the interphase a reddish brown colour indicates the presence of terpenoids in the extracts [10].

\section{Flavonoids (Ammonium Test)}

A small amount of the plant extract is heated with $10 \mathrm{ml}$ of Ethyl acetate in boiling water for 3 minutes. The mixture was filtered and the filtrates were used for the following test. The filtrate was shaken with $1 \mathrm{ml}$ of dilute ammonia solution $(1 \%)$. The layers were allowed to separate. A yellow colouration observed at ammonia layer which indicates the presence of the flavonoids in the plant extract [11].

\section{Phenols ( Ellagic Acid Test)}

The TT plant extract solution was treated with few drops of $5 \%$ (w / v) glacial acetic acid was added and $5 \%$ (w / v) $\mathrm{NaNO}_{2}$ solution. The solution turned into neither muddy nor Niger brown precipitate occurred. Hence, the presence of phenols was confirmed [11]

Saponins (Haemolytic test)

$2 \mathrm{~g}$ of TT extract was mixed with $4 \mathrm{ml}$ of water. The mixtures were shaken vigorously. Formation of froth at $2 \mathrm{~cm}$ showed the presence of saponins. The degree of froth formed determines the quantity of saponins present in extracts [12].

\section{Tannins (Ferric chloride test)}

The presence of tannin in the extract was done by taking $5 \mathrm{ml}$ of extract in a test tube and added few drops of $0.1 \%$ Ferric chloride solution. A bluish black color / brownish green precipitation indicates the presence of tannins [13].

\section{Alkaloids (Mayer's Test )}

The plant extract was warmed with $2 \% \mathrm{H} 2 \mathrm{SO} 4$ for two minutes. It is filtered and few drops of Mayer's reagents were added separately, examined white colour precipitates indicate the positive result [11].

\section{Protein (Biuret test)}

Mixed $2 \mathrm{gm}$ of extract in $4 \mathrm{ml}$ of $40 \%$ sodium hydroxide solution, followed by 2 - 10 drops of $1 \%$ copper sulphate were added. Formation of violet colour confirmed the presence of proteins [14].

\section{Amino acids (Ninhydrin test)}

About $0.5 \mathrm{mg}$ of extract was taken and 2 drops of freshly prepared 0.2 Ninhydrin reagents were added and heated. The appearance of purple or pink colour indicates the presence of protein, peptides and amino acid [15]

\section{Test for resins}

In $2 \mathrm{ml}$ of extract, about $5-10 \mathrm{ml}$ of acetic anhydride was added and dissolved by gentle heating. The solution was cooled and about $0.5 \mathrm{ml}$ of concentrated $\mathrm{H}_{2} \mathrm{SO}_{4}$ was added. The formation of bright purple colour which immediately changed to violet colour indicated the presence of resins[11].

\section{Detection of oils}

Test solution was applied to filter paper it developed a transparent appearance in the filter paper. It indicates the presence oil [15].

\section{Carbohydrate (Benedict's test)}

Crude extract (1gm) was mixed with $2 \mathrm{ml}$ of Benedict's reagent (alkaline solution containing cupric citrate complex) and boiled in water bath; the formation of reddish brown precipitate confirmed the presence of carbohydrates [12].

\section{Detection of steroids}

Dissolved $1 \mathrm{~g}$ of crude extract in $2 \mathrm{ml}$ of Chloroform, $2 \mathrm{ml}$ of conc. $\mathrm{H}_{2} \mathrm{SO}_{4}$ was added followed by 
addition of $2 \mathrm{ml}$ of acetic acid. The formation of bluish green colour indicates the presence of steroids [12].

\section{Glycosides (Keller killiani test)}

In $2 \mathrm{ml}$ of plant extract, glacial acetic acid, one drop of $5 \% \mathrm{FeCl}_{3}$ and conc. $\mathrm{H}_{2} \mathrm{SO}_{4}$ were added. Reddish brown colour appears at intersection of the two liquid layers and in upper layer appears bluish green confirms the presence of glycosides [11].

Quantitative phytochemical analysis of Tribulus terrestris: Alkaloids

$2 \mathrm{~g}$ of the sample in $250 \mathrm{ml}$ beaker, $120 \mathrm{ml}$ of $10 \%$ acetic acid in ethanol was added, covered and allowed to stand for 4 hours. This was filtered and the extract was concentrated on a water bath to one quarter of the original volume. Concentrated ammonium hydroxide was added drop wise to the extract until precipitation was complete .The whole solution allowed to settle and the precipitate was collected and washed with dilute ammonium hydroxide and the filtered. The residue is the alkaloid which was dried and weighed [16].

\section{Flavonoids}

$2 \mathrm{~g}$ of the plant sample was extracted repeatedly with $20 \mathrm{ml}$ of $80 \%$ aqueous methanol at room temperature. The whole solution was filtered through Whatman filter paper No $42(125 \mathrm{~mm})$ the filtrate was later transferred into a crucible and evaporated into dryness and weighed to a constant weight [17].

\section{Thin Layer Chromatography:}

The crude Ethyl acetate extract of Tribulus terrestris subjected to Thin Layer Chromatographic analysis.TLC plates were prepared by using Silica gel as absorbant $.15 \mathrm{gm}$ Silica gel $-\mathrm{G}$ was mixed with $30 \mathrm{ml}$ of distilled water (1:2) to make slurry. The slurry was immediately poured in to the plates. Plates were then allowed to air dry for one hour and using a micropipette about $10 \mu \mathrm{l}$ of the extracts were loaded gradually over the plate. Solvent systems used were chloroform and Methanol in the ratio 5:1.TLC spots were visualized under UV light and adequate TLC reagents were used to detect the phytoconstituent. Individual $\mathrm{Rf}$ value for each spot was measured and calculated using the following formula:

$$
R f=\frac{\text { Distance travelled by solute }}{\text { Distance travelled by solvent }}
$$

\section{RESULT AND DISCUSSION}

In this present study the pharmaceutically active leaf extract of Tribulus terrestris Figure 1 collected in and around Gobichettipalayam, Tirupur and Erode districts. The qualitative phytochemical test for the extract was performed. For this investigation seven solvents were chloroform, Ethyl acetate, Petroleum ether, Methanol, Ethanol, Aqueous and Acetone shown in Figure 2. The presence of many phytochemical bioactive thirteen compounds such as
Terpenoids, Flavonoids ,Phenols , Saponins Tannins, Alkaloids, Proteins, Amino acids, Resins, oils, carbohydrates, Steroids and Glycosides were studied Table 1. Ethyl acetate of TT leaf contains totally seven phytoactive components out of thirteen compounds. They were terpenoids, phenol, saponins, alkaloids, aminoacids, steroids, glycosides and the results revealed the presence of medically active compounds, it could be seen that proteins, steroids, alkaloids, flavonoids, phenols, glycosides and tannins were highly present in the ethanolic extract which are similar to the previous reports of Gomathi et al[18].Acetate extract of TT leaf contains 3 components (saponins, tannins and steroids) and terpenoids, saponins, proteins, steroids and glycosides were present in chloroform extract. Whereas in petroleum ether extract contains only protein out of thirteen component. The aqueous extract of TT leaf contains flavonoids and proteins. Finally the results revealed that ethanol and ethyl acetate has good extractability solvent Fig.4.Such bioactive and phyto constituents may be responsible for various pharmacological actions of this plant part like antibacterial, anticancer, antiulcer, cardio protective and chemo protective activities as suggested by Chhabra et al[19].

The amount of total Tannins, Alkaloids, and Flavonoids in the Ethyl acetate extract of Tribulus terrestris was determined by the standard methods Figure 3. The total Tannin content of the Ethyl acetate extracts $2.76 \mu \mathrm{g} / \mathrm{ml}$ followed by the total Alkaloid content of the Ethyl acetate extracts $0.56 \mathrm{mg} / \mathrm{ml}$ followed by the minimum amount of flavonoids content of the Ethyl acetate extract $0.45 \mathrm{mg} / \mathrm{ml}$ Fig.4. This result is an agreement with the results of Tariq and Reyaz [20], prove that among the different extract the maximum compound was derived from tannin content was found to be $0.96 \mathrm{mg} / \mathrm{ml}$ in biomedically active plant of Tribulus terrestris.

The active phytochemical components were detected by thin layer chromatography. Using this TLC analysis differentiated between monomeric and dimeric forms of flavonoids. In this study the TLC bioautography was performed against the Ethyl acetate plant extracts. In majority of the extract tested by TLC bioautography, phenol, tannin was observed as the most common active constituents. In Figure $5 \&$ Table 2 shows TLC (Thin Layer Chromatography) for various fractions of TT leaf ethyl acetate extracts.

\section{CONCLUSION}

Recurrently the growing interest in plant secondary metabolites has encouraged the need to review the traditional phytochemical extraction technologies and develop new economical, efficient and rapid extraction technologies for enhancing the concentration of phytochemical. The fact that one single plant can contain up to several thousand secondary metabolites, makes the need for development of high performance and rapid extraction methods an absolute 
necessity. The present study has attempted to point out the comparative evaluation of qualitative and quantitative phytochemical analysis of south Indian plant leaf extracts of Tribulus terrestris. Indeed the exact biomedically important phytochemical components identification is in under investigation. Antibacterial activity of TT leaf extract against wound pathogens were reported [9]

\section{Figures and Tables}

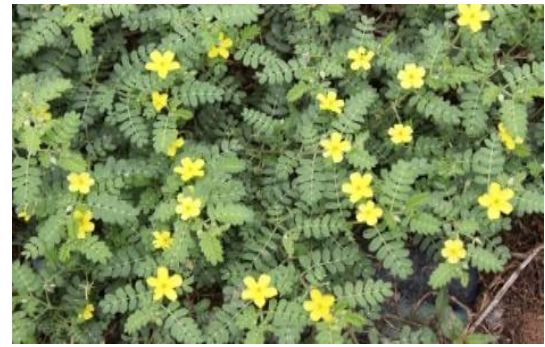

Figure 1: Tribulus terrestris

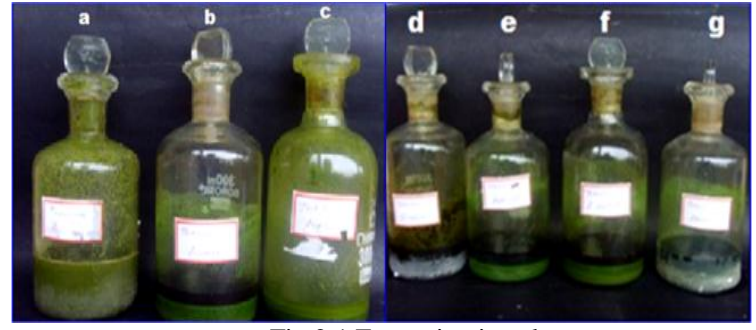

Fig.2.1.Extraction in solvents

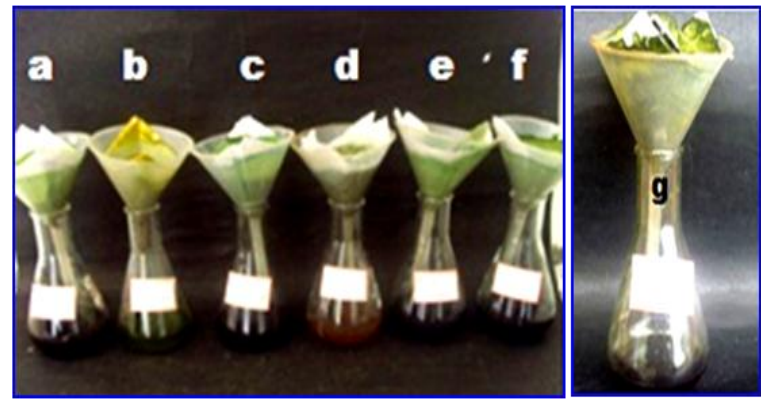

Fig.2.2. Filtration of extracts

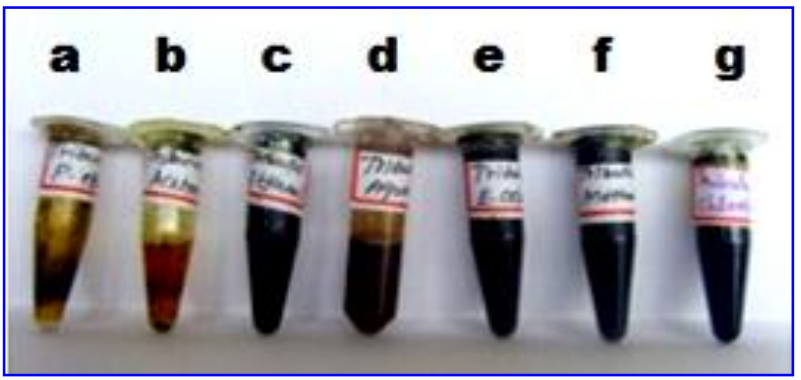

Fig.2.3.Crude extract of TT leafs

Figure 2 : Extraction of Solvent from bioactive leaf of Tribulus terrestris a) Petroleum ether b) Acetone c) Ethanol d) Aqueous e) Ethyl acetate f) Methanol g) Chloroform
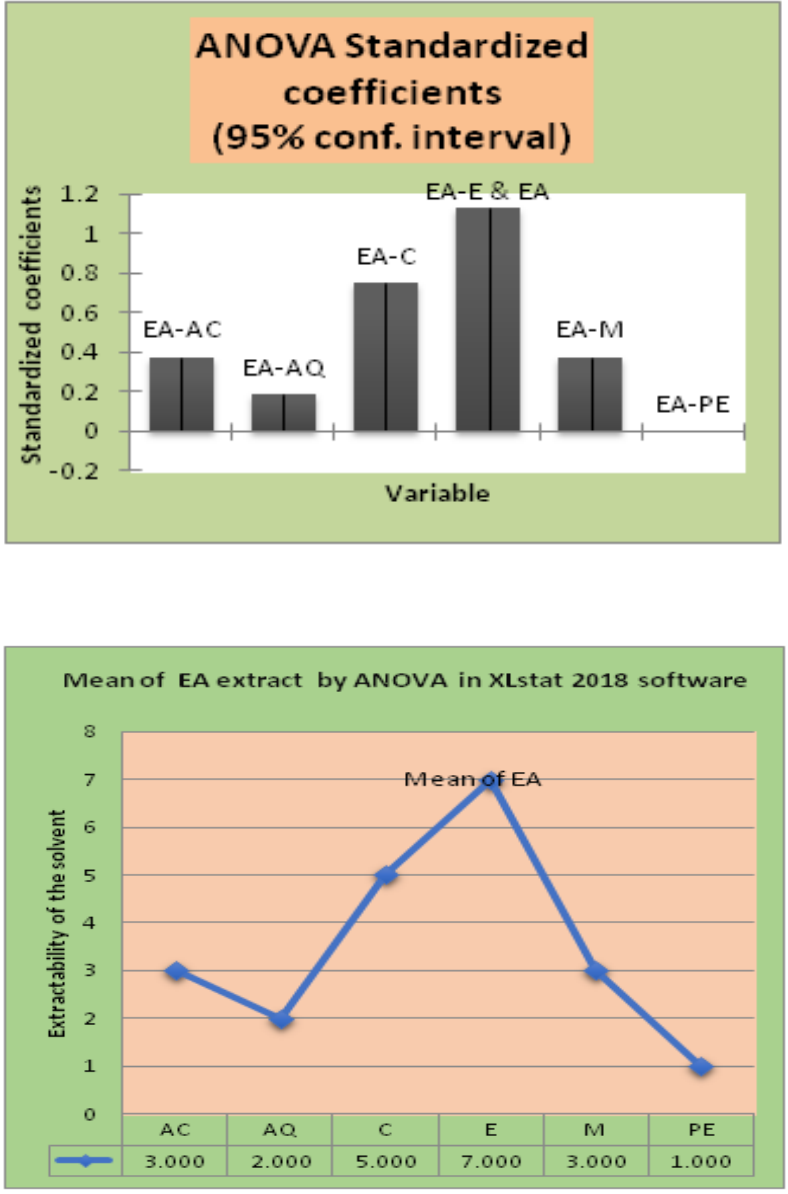

Figure 3: Analysis of best extraction solvent of TT by using XLstat software version 2018.5,Addinsoft (EA-AC extract of acetone, AQ aqueous, $\mathrm{C}$ chloroform, $\mathrm{E}$ ethanol, EA-Ethyl acetate, $\mathrm{M}$ methanol, $\mathrm{PE}$ petroleum ether

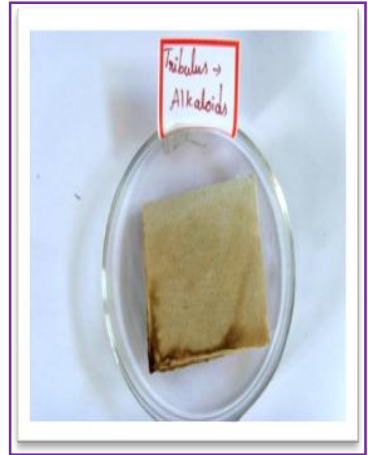

Alkaloids

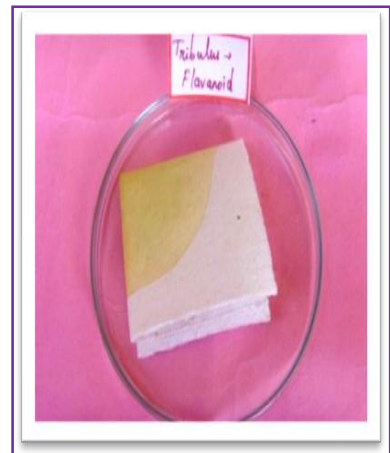

Flavonoids

Figure 4.Quantitative analysis of EA extract of TT leaf 


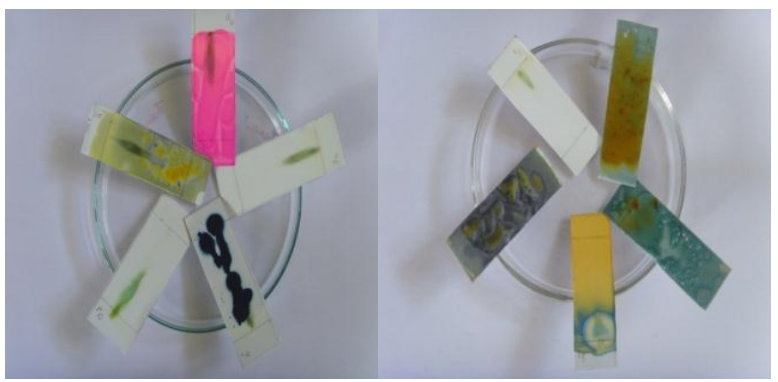

Fraction:a1-a5

Fraction: b1-b5

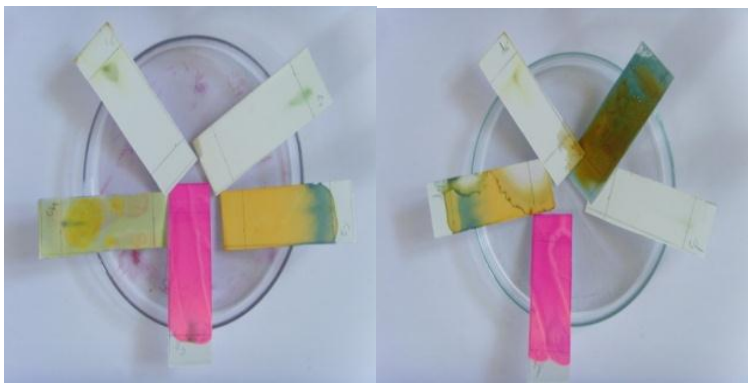

Fraction:c1-c5

Fraction :d1-d5

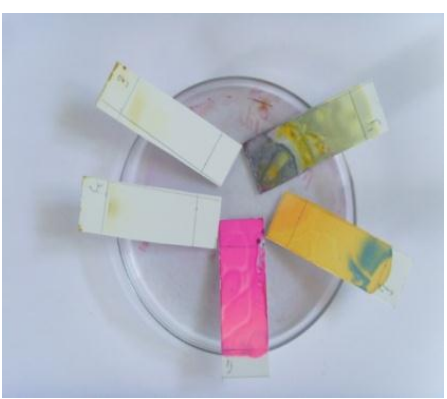

Fraction $\mathrm{f} 1-\mathrm{f} 4$, fe

Figure 5. TLC for various Ethyl acetate extract of Tribulus terrestris (Fa1-Aromatic compounds, Fa2, Fb4, Fc1,-Aminoacid, Fa3, Fb3, Fc4, Ff1-Phenol, Tannin, Fa4, Fc3, Fd2,-Lipid, Fa5, Fb5, Fc5, Fd4, Ff4Iodine, Fb2, Fc2, Fd3, Ff2, Fe-Organic acid)

Table 1: Phytochemical analysis of leaf extracts of Tribulus terrestris (TT)

\begin{tabular}{|c|c|c|c|c|c|c|c|c|c|c|}
\hline \multirow{2}{*}{$\begin{array}{l}\text { S. } \\
\text { No }\end{array}$} & \multirow{2}{*}{$\begin{array}{l}\text { Phyto } \\
\text { compon } \\
\text { ents }\end{array}$} & \multirow{2}{*}{$\begin{array}{l}\text { Reagen } \\
t\end{array}$} & \multirow{2}{*}{$\begin{array}{l}\text { Appear } \\
\text { ance }\end{array}$} & \multicolumn{7}{|c|}{ Solvents } \\
\hline & & & & $\begin{array}{l}\mathbf{E} \\
\mathbf{A}\end{array}$ & M & $\mathbf{E}$ & $\begin{array}{l}\mathbf{A} \\
\mathbf{C}\end{array}$ & $\mathbf{C}$ & $\begin{array}{l}\mathbf{P} \\
\mathbf{E}\end{array}$ & $\begin{array}{l}\mathbf{A} \\
\mathbf{Q}\end{array}$ \\
\hline 1 & $\begin{array}{l}\text { Terpeno } \\
\text { ids }\end{array}$ & $\begin{array}{l}\text { Conc. } \\
\text { Sulphur } \\
\text { ic acid }\end{array}$ & $\begin{array}{l}\text { Grayish } \\
\text { colour }\end{array}$ & - & - & + & - & + & - & - \\
\hline 2 & $\begin{array}{l}\text { Flavono } \\
\text { ids }\end{array}$ & $\begin{array}{l}\text { HCL } \\
\text { and } \\
\text { Zinc or } \\
\text { Magnes } \\
\text { ium }\end{array}$ & $\begin{array}{l}\text { Reddish } \\
\text { pink or } \\
\text { dirty } \\
\text { brown }\end{array}$ & - & - & - & - & - & - & + \\
\hline 3 & Phenol & $\begin{array}{l}\text { Ferric } \\
\text { chlorid } \\
\text { e }\end{array}$ & $\begin{array}{l}\text { Blue or } \\
\text { green } \\
\text { colour }\end{array}$ & + & - & + & - & - & - & - \\
\hline
\end{tabular}

\begin{tabular}{|c|c|c|c|c|c|c|c|c|c|c|}
\hline 4 & $\begin{array}{l}\text { Saponin } \\
\mathrm{s}\end{array}$ & $\begin{array}{l}\text { Sodium } \\
\text { Carbon } \\
\text { ate }\end{array}$ & $\begin{array}{l}\text { Honey } \\
\text { comb } \\
\text { like forth }\end{array}$ & + & + & + & + & + & - & - \\
\hline 5 & Tannins & $\begin{array}{l}\text { Ferric } \\
\text { chlorid } \\
\mathrm{e} \\
\end{array}$ & $\begin{array}{l}\text { Bluish } \\
\text { black } \\
\text { colour }\end{array}$ & + & - & - & + & - & - & - \\
\hline 6 & $\begin{array}{l}\text { Alkaloid } \\
\text { s }\end{array}$ & $\begin{array}{l}\text { Mayer' } \\
\text { s } \\
\text { reagent }\end{array}$ & $\begin{array}{l}\text { Pale } \\
\text { yellow }\end{array}$ & + & + & + & - & - & - & - \\
\hline 7 & Protein & $\begin{array}{l}\text { NaoH } \\
\text { and } \\
\text { copper } \\
\text { sulphat } \\
\text { e } \\
\end{array}$ & $\begin{array}{l}\text { Violet } \\
\text { colour }\end{array}$ & - & - & - & - & + & + & + \\
\hline 8 & $\begin{array}{l}\text { Aminoa } \\
\text { cids }\end{array}$ & $\begin{array}{l}\text { Ninhyd } \\
\text { rin } \\
\text { reagent }\end{array}$ & $\begin{array}{l}\text { Pink or } \\
\text { purple } \\
\text { colour }\end{array}$ & - & + & + & - & - & - & - \\
\hline 9 & Resins & $\begin{array}{l}\text { Acetic } \\
\text { anhydri } \\
\text { de and } \\
\text { Conc. } \\
\text { Sulphur } \\
\text { ic acid }\end{array}$ & $\begin{array}{l}\text { Bright } \\
\text { purple } \\
\text { colour }\end{array}$ & - & - & - & - & - & - & - \\
\hline 10 & Oils & - & $\begin{array}{l}\text { Transpar } \\
\text { ence }\end{array}$ & - & - & - & - & - & - & - \\
\hline 11 & $\mathrm{CHO}$ & $\begin{array}{l}\text { Benedi } \\
\text { ct's } \\
\text { reagent }\end{array}$ & $\begin{array}{l}\text { Reddish } \\
\text { brown }\end{array}$ & - & - & - & - & - & - & - \\
\hline 12 & Steroids & $\begin{array}{l}\text { Acetic } \\
\text { anhydri } \\
\text { de and } \\
\text { sulphur } \\
\text { ic acid }\end{array}$ & $\begin{array}{l}\text { Violet or } \\
\text { blue or } \\
\text { green }\end{array}$ & + & - & + & + & + & - & - \\
\hline 13 & $\begin{array}{l}\text { Glycosi } \\
\text { des }\end{array}$ & $\begin{array}{l}\text { Glacial } \\
\text { acetic } \\
\text { acid, } \\
\text { ferric } \\
\text { chlorid } \\
\text { e }\end{array}$ & $\begin{array}{l}\text { Bluish } \\
\text { green } \\
\text { colour }\end{array}$ & + & - & + & - & + & - & - \\
\hline
\end{tabular}

Note:+ sign indicates presence of phytocompounds, - sign indicates absence of phytocompounds (EA-Ethyl acetate, M-Methanol, EEthanol, AC-Acetone, C-Chloroform, PE-Petroleum ether, AQAqueous)

Table 2: TLC (Thin Layer Chromatography) for various fraction using Ethyl acetate extract for Tribulus terrestris

\begin{tabular}{|l|l|l|l|l|l|}
\hline $\begin{array}{l}\text { Fracti } \\
\text { on }\end{array}$ & $\begin{array}{l}\text { Sub } \\
\text { Fract } \\
\text { ion }\end{array}$ & $\begin{array}{l}\text { RF } \\
\text { value }\end{array}$ & Compounds & Colour & $\begin{array}{l}\text { Present/ } \\
\text { Absent }\end{array}$ \\
\hline \multirow{3}{*}{$\mathrm{Fa}$} & Fa1 & 0.75 & $\begin{array}{l}\text { Aromatic } \\
\text { compound }\end{array}$ & Blue colour & Absent \\
\cline { 2 - 6 } & $\mathrm{Fa} 2$ & 0.75 & Amino acid & $\begin{array}{l}\text { Reddish } \\
\text { spot }\end{array}$ & Absent \\
\cline { 2 - 6 } & $\mathrm{Fa} 3$ & 0.75 & Phenol, tannin & $\begin{array}{l}\text { Yellow } \\
\text { transparent }\end{array}$ & Present \\
\cline { 2 - 6 } & $\mathrm{Fa} 4$ & 0.75 & Lipid & Red spot & Absent \\
\cline { 2 - 6 } & $\mathrm{Fa} 5$ & 0.75 & Iodine & Brown spot & Present \\
\hline \multirow{3}{*}{ Fb } & Fb1 & 0.87 & Organic compound & $\begin{array}{l}\text { Brown } \\
\text { greenish } \\
\text { back }\end{array}$ & Present \\
\cline { 2 - 6 } & Fb2 & 0.87 & Organic acid & $\begin{array}{l}\text { Yellow } \\
\text { blue back }\end{array}$ & Present \\
\cline { 2 - 6 } & Fb3 & 0.87 & Phenol,tannin & $\begin{array}{l}\text { Yellow } \\
\text { transparent }\end{array}$ & Present \\
\hline
\end{tabular}




\begin{tabular}{|l|l|l|l|l|l|}
\hline \multirow{5}{*}{ Fc } & Fb4 & 0.87 & Amino acid & $\begin{array}{l}\text { Reddish } \\
\text { spot }\end{array}$ & Absent \\
\cline { 2 - 6 } & Fb5 & 0.87 & Iodine & Brown spot & Present \\
\cline { 2 - 6 } & Fc1 & 0.95 & Amino acid & $\begin{array}{l}\text { Reddish } \\
\text { spot }\end{array}$ & Absent \\
\cline { 2 - 6 } & Fc3 & 0.95 & Organic acid & $\begin{array}{l}\text { Yellow } \\
\text { blue back }\end{array}$ & Present \\
\cline { 2 - 6 } & Fc4 & 0.95 & Phenol,tannin & $\begin{array}{l}\text { Red spot } \\
\text { Yellow } \\
\text { transparent }\end{array}$ & Absent \\
\cline { 2 - 6 } & Fc5 & 0.95 & Iodine & Brown spot & Present \\
\hline \multirow{4}{*}{ Fd } & Fd1 & 0.83 & Organic compound & $\begin{array}{l}\text { Brown } \\
\text { greenish } \\
\text { back }\end{array}$ & Present \\
\cline { 2 - 6 } & Fd2 & 0.83 & Lipid & Red spot & Absent \\
\cline { 2 - 6 } & Fd3 & 0.83 & Organic acid & $\begin{array}{l}\text { Yellow } \\
\text { blue back }\end{array}$ & Present \\
\cline { 2 - 6 } & Fd4 & 0.83 & Iodine & Brown spot & Present \\
\hline Fe & Fe1 & 0.97 & Organic acid & $\begin{array}{l}\text { Yellow } \\
\text { blue back }\end{array}$ & Present \\
\hline \multirow{3}{*}{ Ff } & Ff1 & 0.92 & Phenol,tannin & $\begin{array}{l}\text { Yellow } \\
\text { transparent }\end{array}$ & Present \\
\cline { 2 - 6 } & Ff2 & 0.92 & Organic acid & $\begin{array}{l}\text { Yellow } \\
\text { blue back }\end{array}$ & Present \\
\cline { 2 - 6 } & Ff3 & 0.92 & Lipid & Red spot & Absent \\
\hline
\end{tabular}

\section{REFERENCES}

[1]. Ankitha Sudheendran and Shajahan M.A, "Pharmacognostical and phytochemical evaluation of root and fruit of gokshura (Tribulus terrestris Linn) ", International Ayurvedic medical Journal,Vol. 5, Issue 10,pp.3704-3713,2017

[2]. Doughari JH, "Phytochemical: Extraction methods, basic structures and mode of action as potential chemotherapeutic agents, phytochemicals - A global perspective of their role in nutrition and health" ,Dr Venketeshwer Rao (Ed.). InTech ISBN: 978- 953-51-0296-0,2012

[3]. Christudas S, Kulathivel TM and Agastian P, "Phytochemical and antibacterial studies of leaves of Tridax procumbens L",Asian Pacific Journal of Tropical Biomedicine. pp.S159-S161,2012

[4]. Udayaprakash NK, S. Bhuvaneswari, S. Preethy, N. Rajalakshmi, M. Saranya, A Jasmine R. and Arokiyaraj. S, "Studies on antimicrobial, antioxidant, larvicidal, pesticidal activity and Phytochemistry of leaves of Alangium salvifolium (L.F.) Wang", International Journal of Pharmacy and Pharmaceutical Sciences,Vol. 5,pp. 86-89, 2013

[5]. Jalpa R, Moteriya $\mathrm{P}$ and Chanda S“Phytochemical screening and reported biological activities of some medicinal plants of Gujarat region" Journal of Pharmacognosy and Phyto chemistry, Vol. 4, Issue 2,pp.192- 198,2015

[6]. Veerachari U and Bopaiah AK "“ Preliminary phytochemical evaluation of the leaf extract of five Cassia Species", Journal of Chemical and Pharmaceutical Research,Vol. 3, Issue 5: pp.574583,2011

[7]. Nandagoapalan V, Doss A and Marimuthu C,"Phytochemical analysis of some traditional medicinal plants",Bioscience Discovery, Vol. 7, Issue.1,pp.17-20,2016

[8]. Kumar A "Comparative and quantitative determination of quercetin and other flavonoids in north Indian populations of Tribulus terrestris Linn by HPLC", International Journal of Pharma Bio Sciences, Vol. 3, Issue .4: pp.69-79,2012

[9]. M.S.Uma Maheswari,R.Rajendran and S.Vijayalakshmi, "Pharmacological activity of different solvent extracts of TT against multi drug resistant Staphylococcus aureus isolated from post operative wound patients",Bioscience Biotechnological Research communication,Vol.10,Issue.4,pp.75276,DOI: $10.21786 / \mathrm{bbrc} / 10.4 / 22,2017$

[10].Evans,W.C Pharmacology, Harcourt Brace and Company Asia Pvt.Ltd,Singapore. Pp.226 - 227,1997

[11].H.O.Edeoga,D.E.Okwu and B.O.Mbaebie, "Phytochemical constituents of some Nigerian medical plants",African journal of Biotechnology,Vol.4,Issue.7,pp.685-688,2005

[12].Yadav R and Agarwala M, "Phytochemical analysis of some medicinal plants",Journal of Phytology,Vol.3,Issue.12,pp.1014,2011

[13].Segelman,A.B.,Farnsworth,N.R.,Quimby,M.D,“ Fales - Negative saponins test results induced by the presemce of tannins" J Biol Chem,Vol.32,Issue.2,pp.52-58,1969

[14]. Salwaan,C., Singh,A., Mittal,A. and Singh,P, "Investigation of the pharmacognostical ,phytochemical and antioxidant studies of plant withania coagulants Dunal".J.Pharmacognosy and Phytochemistry,Vol.1,Issue.3,pp.32-39,2012

[15].Santhi K and Sengottuvel R, "Qualitative and Quantitative phytochemical analysis Moringa concanensis Nimmo" .Int.J.Curr.Microbiol.App.Sci Vol.5,Issue.1:pp.633-640,2016

[16].Mehmooda Munazir, Rahmatullah Qureshi and Mubashrah Munir Pak. J. Bot, Vol.47,Issue.2,pp.659-664, 2015

[17].Chang, C., M. Yang, H. Wen and J. Chern, "Estimation of total Flavonoid content in propolis by two complementary colorimetry method" .J.Food Drug Anal., Vol.10,Issue.3,pp. 178-182,2002

[18].Gomathi S, Shanmugapriya A, Bharathi V, Gayathri G, Karpagam $\mathrm{T}$ "Antimicrobial activity and phytochemical studies of aqueous and ethanolic extract of Tribulus terrestris" IJPIS Journal of Pharmacognosy and Herbal Formulations,Vol. 2,pp.1-8,2012

[19].Chhabra S.C, Viso FC and Mshiv EN, "Phytochemical screening of Tanzanian medicinal plants", Int. J. Ethao pharmacol. Vol. 11: pp. $157-179,1984$

[20].Tariq A.L and Reyaz A.L, "Quantitative phytochemical analysis of traditionally used medicinal plant Terminilia chebula" International Research Journal of Biotechnology,Vol. 4, Issue 5,pp.101-105,2013

\section{AUTHORS PROFILE}

Mrs.M.S.Uma maheswari B.Sc.,M.Sc.,Ph.D (pursuing-part time) in Microbiology. She is currently working as Associate Professor in Department of Microbiology from Tiruppur Kumaran College for Women,Tirupur,TN,India.She has more then 15 years of teaching experience.Her main research focus on Phytochemical analysis and their antimicrobial activity.Guided many M.Sc.,Microbiology students. 